\title{
Studi Karakteristik Bio-briket Berbahan Baku Limbah Kulit Batang Sagu dan Tempurung Kelapa
}

\section{Study of Characteristics of Bio-briquettes Made from Combination of Sago Bark and Coconut Shell}

\author{
Jerry M. Karamoy ${ }^{1}$, Budi Santoso ${ }^{1}$, Sarman Oktovianus Gultom ${ }^{1 *}$ \\ ${ }^{1}$ Jurusan Teknologi Pertanian, Fakultas Teknologi Pertanian, Universitas Papua \\ Jl. Gunung Salju Amban, Maokwari. \\ *Email:s.gultom@unipa.ac.id
}

\begin{abstract}
The purpose of this study was to know the characteristics of bio-briquette which resulted from combination of sago bark and coconut shell. The method used in this study was an experimental method with 5 different treatments. The treatments were denoted by the letter $S$ for Sago bark, and letter $K$ for coconut shell, where (1) $S_{10} K_{0}$ (100\% of sago bark charcoal) (2) $S_{7,5} K_{2,5}$ (75\% of sago bark charcoal and $25 \%$ of coconut shell charcoal) (3) $S_{5} K_{5}$ (50\% of both sago bark and coconut shell charcoal) (4) $S_{2.5} K_{7,5}$ (25\% of sago bark charcoal and $75 \%$ of coconut shell charcoal), and (5) $S_{0} K_{10}$ (100\% of coconut shell charcoal). Parameters observed in this study included the rendemen of the charcoal, vapor content, ash content, and duration of ignition. The results showed that the rendemen of sago bark charcoal is $14 \%$ and the rendemen of coconut shell charcoal is $15 \%$. The ash content ranges from $4.23 \%$ to $14.4 \%$, the vapor content ranges from $3.15-3.71 \%$, the heat value ranges from 114-168 Cal / g, while the duration of ignition ranges from 3400 to 4180 seconds per 10 gram of biobriquette. The addition of coconut shell charcoal to the production of sago bark bio-briquettes tends to increase the duration of ignition, but tends to decrease ash content. The best combination of biobriquette is a combination with $25 \%$ of sago bark charcoal and $75 \%$ coconut shell charcoal $\left(S_{2,5} K_{7,5}\right)$ with 5,08\% of moisture content, 4,93\% of ash content, 3,27\% of vapor content, and 398 second/g for the duration of ignition.
\end{abstract}

Keywords: Bio briquette, waste, sago bark, coconut shell.

\begin{abstract}
Abstrak
Tujuan penelitian ini adalah untuk mengetahui karakteristik biobriket yang dihasilkan dari kombinasi limbah kulit batang sagu dan tempurung kelapa. Metode yang digunakan dalam penelitian ini adalah metode eksperimen dengan Rancangan Acak Lengkap. Pada penelitian ini digunakan 5 perlakuan dengan 3 kali pengulangan. Perlakuan dinotasikan dengan huruf $\mathrm{S}$ (Kulit batang sagu), dan $\mathrm{K}$ (tempurung kelapa) dimana (1) $\mathrm{S}_{10} \mathrm{~K}_{0}$ arang kulit batang sagu $100 \%$ (2) $\mathrm{S}_{7,5} \mathrm{~K}_{2,5}$ arang kulit batang sagu $75 \%$ dan arang tempurung kelapa $25 \%$ (3) $\mathrm{S}_{5} \mathrm{~K}_{5}$ arang kulit batang sagu $50 \%$ dan arang tempurung kelapa $50 \%$ (4) $\mathrm{S}_{2,5} \mathrm{~K}_{7,5}$ arang kulit batang sagu $25 \%$ dan arang tempurung kelapa $75 \%$ (5) $\mathrm{S}_{0} \mathrm{~K}_{10}$ arang tempurung kelapa $100 \%$. Parameter yang diamati pada penelitian ini meliputi rendemen, kadar zat menguap, kadar abu, dan lama penyalaan. Secara keseluruhan nilai rendemen arang kulit batang sagu sebesar $14 \%$ dan nilai rendemen arang tempurung kelapa sebesar $15 \%$. Kadar abu berkisar antara 4,23-14,4\%, kadar zat menguap berkisar antara 3,15-3,71\%, nilai kalor berkisar antara 114-168 Cal/g, sedangkan lama penyalaan berkisar selama 3400-4180 detik. Penambahan arang tempurung kelapa pada pembuatan biobriket kulit batang sagu cenderung meningkatkan lama penyalaan, namun cenderung menurunkan kadar abu. Kombinasi terbaik dalam pembuatan biobriket adalah kombinasi dengan ratio $25 \%$ arang kulit batang sagu dan $75 \%$ arang tempurung kelapa $(\mathrm{S} 2,5 \mathrm{~K} 7,5)$ dengan nilai kadar air sebesar 5,08\%, kadar abu sebesar 4,93\%, kadar zat menguap sebesar $3,27 \%$, dan lama penyalaan selama $3980 \mathrm{detik} / \mathrm{gram}$.
\end{abstract}

Kata kunci: Biobriket, limbah, kulit batang sagu, tempurung kelapa. 


\section{PENDAHULUAN}

Ketergantungan penduduk di Indonesia terhadap energi fosil terutama minyak bumi dalam pemenuhan kebutuhan di dalam negeri masih tinggi yaitu sebesar $96 \%$ (minyak bumi $48 \%$, gas $18 \%$ dan batu bara $30 \%$ ). Tingginya konsumsi energi fosil tersebut diakibatkan oleh subsidi yang diterapkan oleh pemerintah, sehingga harga energi fosil menjadi murah dan masyarakat cenderung boros dalam menggunakan energi fosil (Dewan Energi Nasional, 2014). Dari permasalahan tersebut maka perlu diupayakan penggunaan energi alternatif yang sifatnya dapat terbarukan.

Beberapa jenis sumber energi terbarukan yang dapat dikembangkan antara lain energi matahari, energi angin, energi air, dan energi biomassa. Draha (2009) mengatakan bahwa diantara sumber-sumber energi alternatif tersebut, energi biomassa merupakan sumber energi alternatif yang perlu untuk dikembangkan. Biomassa merupakan bahan alami yang biasanya dianggap sebagai sampah. Biomassa salah satunya dapat diolah menjadi biobriket, yang merupakan bahan bakar dengan tingkat nilai pembakaran yang cukup tinggi sehingga dapat digunakan dalam kehidupan sehari-hari.

Di Indonesia khususnya di daerah Papua, sagu merupakan salah satu tanaman penghasil karbohidrat unggulan yang dimanfaatkan oleh masyarakat untuk berbagai jenis olahan. Pada proses pengolahan sagu, berbagai jenis limbah dihasilkan seperti hampas, limbah cair hasil ekstraksi dan kulit batang sagu (Gultom dkk., 2016). Limbah kulit batang sagu hingga saat ini belum dimanfaatkan secara optimal. Singhal -dkk., (2008) mengatakan bahwa secara terbatas, masyarakat memanfaatkan limbah kulit batang sagu sebagai alas lantai dan dinding rumah sedangkan sebagian besar limbah kulit batang sagu masih dibiarkan membusuk, ditumpuktumpuk, dan dibakar. Kiat (2006) mengatakan bahwa kulit batang sagu memiliki kandungan selulosa $57 \%$ dan lignin $38 \%$. Dengan demikian, untuk mengetahui potensi kulit batang sagu sebagai bahan baku pembuatan biobriket maka penelitian ini penting untuk dilakukan. Penggunaan biobriket dari kulit batang sagu diharapkan dapat mengurangi konsumsi dari bahan bakar minyak (BBM), dan dapat mengurangi ketergantungan masyarakat terhadap bahan bakar fosil.

\section{METODOLOGI}

\section{Bahan dan alat}

Bahan utama yang akan digunakan dalam penelitian ini yaitu kulit batang sagu, tempurung kelapa, kanji, dan air. Kulit batang sagu diperoleh dari limbah proses pengupasan batang sagu yang akan digunakan untuk menghasilkan pati sagu. Tempurung kelapa didapatkan dari para penjual kepala di pasar Sanggeng, Manokwari.

Peralatan yang akan digunakan dalam penelitian ini yaitu drum pengarangan, discmill model FFC-15, ayakan 80 mesh, gelas ukur, pencetak briket, oven listrik, desikator, timbangan analitik, cawan porselin, dan tanur model L 5/P, maks. $1100{ }^{\circ} \mathrm{C}$.

\section{Metode penelitian}

Penelitian ini menggunakan rancangan acak lengkap (RAL) dengan mengkombinasikan jenis bahan pembuat biobriket yaitu kulit batang sagu dan tempurung kelapa seperti disajikan pada Tabel 1. Setiap perlakuan dilakukan 3 kali pengulangan.

Tabel 1. Perbandingan Arang Kulit Batang Sagu Dan Tempurung Kelapa.

\begin{tabular}{ccc}
\hline \multirow{2}{*}{$\begin{array}{c}\text { Kode } \\
\text { Perlakuan }\end{array}$} & $\begin{array}{c}\text { Arang serbuk } \\
\text { kulit Batang } \\
\text { Sagu }\end{array}$ & $\begin{array}{c}\text { Arang } \\
\text { serbuk } \\
\text { tempurung } \\
\text { Kelapa }\end{array}$ \\
\hline $\mathrm{S}_{10} \mathrm{~K}_{0}$ & $100 \%$ & $0 \%$ \\
$\mathrm{~S}_{7,5} \mathrm{~K}_{2,5}$ & $75 \%$ & $25 \%$ \\
$\mathrm{~S}_{5} \mathrm{~K}_{5}$ & $50 \%$ & $50 \%$ \\
$\mathrm{~S}_{2,5} \mathrm{~K}_{7,5}$ & $25 \%$ & $75 \%$ \\
$\mathrm{~S}_{0} \mathrm{~K}_{10}$ & $0 \%$ & $100 \%$ \\
\hline
\end{tabular}

Pembuatan biobriket berbahan baku limbah kulit batang sagu dan tempurung kelapa dilakukan dengan tahapan berikut: 
Persiapan bahan

Kulit batang sagu dipotong-potong dengan ukuran $30 \mathrm{~cm}$ x $30 \mathrm{~cm}$ kemudian dijemur di bawah sinar matahari. Tempurung kelapa dibersihkan lalu dijemur di bawah sinar matahari. Kedua bahan baku tersebut dijemur selama 2 hari untuk menurunkan kandungan... apa? (tlg dicek).

\section{Karbonisasi}

Proses karbonisasi pada bahan baku yaitu kulit batang sagu dan tempurung kelapa dilakukan secara terpisah. Untuk mengawali proses karbonisasi, terlebih dahulu pada bagian bawah drum diletakkan sabut kelapa, selanjutnya sabut kelapa dibakar. Kemudian masukkan bahan baku ke dalam drum hingga bahan baku terbakar. Pada bagian atas drum dibiarkan terbuka, setelah asap yang ditimbulkan dari proses pembakaran mulai menipis dan bahan baku telah menjadi bara maka penutup drum pada bagian atas ditutup agar oksigen tidak masuk ke dalam drum karbonasi sehingga tidak terjadi nyala api di dalam drum.

\section{Pengecilan ukuran dan pembuatan perekat}

Pengecilan ukuran pada arang kulit batang sagu dan arang tempurung kelapa dilakukan dengan menggunakan mesin discmill dan diayak menggunakan ayakan 80 mesh (Hanandito dan Willy, 2008). Bahan perekat yang digunakan adalah kanji dengan kadar $4 \%$ dari berat serbuk arang. Pembuatan biobriket dilakukan dengan perbandingan kanji: air: serbuk arang adalah 1:17:25. Kanji dan air dimasak hingga membentuk gel, dan selanjutnya dicampur dengan serbuk arang dan diaduk hingga homogen.

\section{Pencetakan}

Hasil adonan dicetak dengan memasukan adonan ke dalam pipa $1 / 2$ inch, dengan panjang pipa $4 \mathrm{~cm}$, selanjutnya dipadatkan menggunakan tangan.

\section{Pengeringan}

Biobriket arang yang dihasilkan kemudian dikeringkan dengan penjemuran matahari selama 2 hari. Waktu optimal yang dibutuhkan untuk mengurangi kadar air hingga maksimal 8\% (SNI, 2000) dibutuhkan waktu 2 hari (Sholichah dan Afifah, 2011).

\section{Penentuan rendemen arang}

Rendemen arang diukur melalui perbadingan antara jumlah arang yang diperoleh dengan berat awal kulit batang sagu sebelum diarangkan. Rendemen dapat dihitung mengunakan Persamaan 1.

Rendemen $(\%)=\frac{\mathrm{M}_{1}}{\mathrm{M}_{2}} \times 100 \%$

$\mathrm{M}_{1}$ : Berat arang setelah pengarang $(\mathrm{kg})$

$\mathrm{M}_{2}$ : Berat bahan sebelum pengarangan $(\mathrm{kg})$

\section{Penentuan kadar abu}

Penentuan kadar abu dilakukan berdasarkan AOAC (2005). Cawan porselin dikeringkan dalam tanur bersuhu $600^{\circ} \mathrm{C}$ selama 30 menit. Selanjutnya cawan didinginkan di dalam desikator selama 30 menit dan ditimbang bobot kosongnya. Sampel dimasukkan sebanyak 1 gram. Cawan yang telah berisi sampel selanjutnya dimasukkan ke dalam tanur dengan suhu $850^{\circ} \mathrm{C}$ selama 4 jam sampai sampel menjadi abu. Selanjutnya cawan diangkat dari dalam tanur dan didinginkan didalam desikator, lalu ditimbang. Kadar abu dapat dihitung dengan menggunakan Persamaan 2

$$
\% \text { kadar abu }=\frac{\mathrm{W}_{1}-\mathrm{W}_{2}}{\mathrm{~W}} \times 100 \%
$$

W: Berat sampel (g)

$\mathrm{W}_{1}$ : Berat cawan + berat abu $(\mathrm{g})$

$\mathrm{W}_{2}$ : Berat cawan kosong $(\mathrm{g})$

\section{Penentuan kadar zat menguap}

Penentuan kadar zat yang menguap dilakukan berdasarkan AOAC (2005). Cawan kosong terlebih dahulu dikeringkan di dalam oven pada suhu $105^{\circ} \mathrm{C}$ selama 1 jam dan didinginkan didalam desikator. Kemudian sampel ditimbang sebanyak 1 gram. Selanjutnya cawan beserta sampel dimasukan ke dalam tanur dengan suhu $950^{\circ} \mathrm{C}$ selama 7 menit. Penentuan kadar zat yang hilang pada suhu $950^{\circ} \mathrm{C}$ dapat dihitung dengan menggunakan persamaan 3 .

Kadar zat hilang pada $950^{\circ} \mathrm{C}(\%)$

$=\underline{\mathrm{W} 1-\mathrm{W} 2} \times 100 \%$

$$
\mathrm{W} 1
$$

W1: Berat sampel awal+cawan (g)

W2: Berat sampel setelah pengabuan+cawan (g) 


\section{Pengujian lama penyalaan}

Uji nyala api dilakukan untuk mengetahui berapa lama waktu biobriket terbakar sampai menjadi abu. Pengujian lama penyalaan dilakukan dengan cara biobriket dibakar. Pencatatan waktu dimulai ketika biobriket menyala hingga biobriket habis atau telah menjadi abu. Pengukuran waktu penyalaan biobriket ini menggunakan stopwatch. Berat masing-masing perlakuan 10 gram.

\section{HASIL DAN PEMBAHASAN}

\section{Biobriket berbahan baku Kulit Batang Sagu dan Tempurung Kelapa}

Kulit batang sagu dan tempurung kelapa, seperti halnya serbuk gergaji, sekam padi, ampas tebu, dan jenis-jenis biomassa lainnya mengandung lignin dan selulosa yang merupakan faktor penting dalam pembakaran (Kiat, 2006). Pada penelitian ini, kulit batang sagu dan tempurung kelapa tidak digunakan secara langsung untuk bahan pembakaran namun dibuat dalam bentuk biobriket yang dimanfaatkan sebagai sumber energi alternatif terbarukan (Gambar 1).

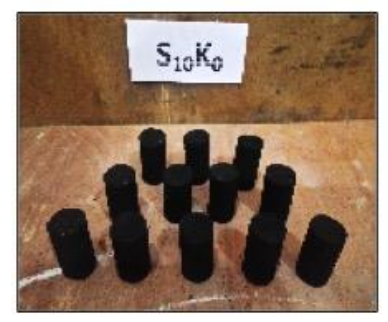

(a)

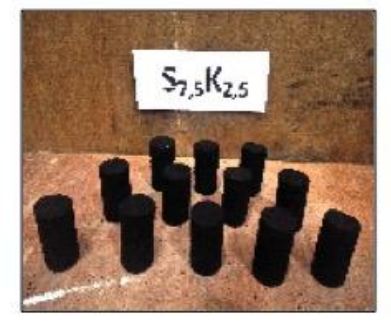

(b)

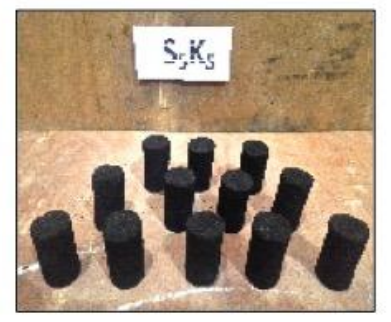

(c)

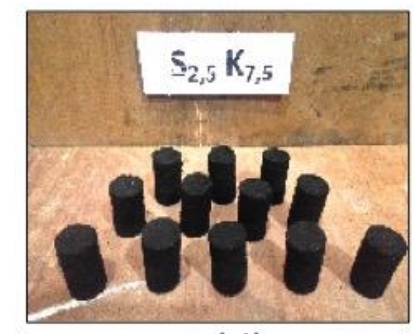

(d)

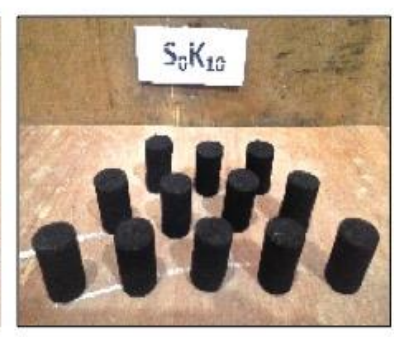

(e)

Gambar 1. Biobriket kulit batang sagu, tempurung kelapa dan kombinasinya (A) $\mathrm{S}_{10} \mathrm{~K}_{0}$ Arang Kulit Batang Sagu $100 \%$ (B) $\mathrm{S}_{7,5} \mathrm{~K}_{2,5}$ Arang Kulit Batang Sagu 75\% Dan Arang Tempurung Kelapa $25 \%$ (C) $\mathrm{S}_{5} \mathrm{~K}_{5}$ Arang Kulit Batang Sagu $50 \%$ Dan Arang Tempurung Kelapa $50 \%$ (D) $\mathrm{S}_{2,5} \mathrm{~K}_{7,5}$ Arang Kulit Batang Sagu $25 \%$ Dan Arang Tempurung Kelapa 75 \% (E) $\mathrm{S}_{0} \mathrm{~K}_{10}$ Arang Tempurung Kelapa $100 \%$.

Hasil pencetakan dari kombinasi perlakuan antara arang kulit batang sagu dan arang tempurung kelapa dikeringkan pada rumah pengering. Tujuan penggunaan rumah pengering dalam pengeringan biobriket ialah mempercepat proses pengeringan. Panas yang dihasilkan didalam rumah pengering bersumber dari energi panas matahari. Suhu didalam rumah pengering berkisar antara 38$44^{\circ} \mathrm{C}$. Biobriket yang dihasilkan berbentuk silinder dengan panjang $4 \mathrm{~cm}$ dan diameter $1 / 2$ inch.

\section{Rendemen}

Rendemen adalah perbandingan jumlah (kuantitas) arang yang dihasilkan dari hasil pembakaran (karbonisasi) dengan jumlah bahan baku sebelum diarangkan. Semakin tinggi nilai rendemen yang dihasilkan menandakan arang yang dihasilkan semakin banyak maka proses karbonisasi berjalan efektif. Rata-rata rendemen arang kulit batang sagu dan tempurung kelapa dapat dilihat pada Tabel 2. 
Tabel 2. Rendemen kulit batang sagu dan tempurung kelapa.

\begin{tabular}{cccccccc}
\hline Jenis bahan & $\begin{array}{c}\text { Sebelum } \\
\text { pengarangan } \\
(\mathrm{kg})\end{array}$ & $\begin{array}{c}\text { Menjadi Arang } \\
\text { Berat } \\
(\mathrm{kg})\end{array}$ & $\begin{array}{c}\text { Persentase } \\
(\%)\end{array}$ & $\begin{array}{c}\text { Menjadi abu } \\
\text { Berat } \\
(\mathrm{kg})\end{array}$ & $\begin{array}{c}\text { Persentase } \\
(\%)\end{array}$ & $\begin{array}{c}\text { Tidak Terbakar } \\
\text { Berat }\end{array}$ & $\begin{array}{c}\text { Persentase } \\
(\%)\end{array}$ \\
\hline $\begin{array}{c}\text { Kulit } \\
\text { batang } \\
\text { sagu }\end{array}$ & 10 & 1,43 & 14 & 6,97 & 69 & 1,7 & 17 \\
$\begin{array}{c}\text { Tempurung } \\
\text { kelapa }\end{array}$ & 10 & 1,53 & 15 & 7,32 & 73 & 1,23 & 12 \\
\hline
\end{tabular}

Rendemen arang yang diperoleh pada penelitian ini berkisar antara 14-15\% (Tabel 2). Rendemen arang kulit batang sagu yaitu sebesar $14 \%$, tidak terkarbonasi $17 \%$, dan $69 \%$ menjadi abu. Sedangkan, rendemen arang tempurung kelapa yaitu $15 \%$, tidak terkarbonasi $12 \%$, dan $73 \%$ menjadi abu. Rendemen pada arang kulit batang sagu dan arang tempurung kelapa relatif rendah karena proses karbonisasi yang tidak sempurna sehingga sebagian besar bahan menjadi abu. Hal ini sejalan dengan Irmanto dan Suyata (2010) yang mengatakan bahwa rendemen arang yang rendah dapat disebabkan oleh jumlah udara saat karbonisasi, dan ukuran bahan baku. Ukuran bahan yang terlalu kecil memungkinkan kehilangan arang dalam jumlah yang relatif banyak karena banyak dihasilkan abu, sedangkan ukuran bahan yang terlalu besar menyebabkan kurang meratanya pengarangan sehingga tidak semua bahan dapat terkarbonisasi secara sempurna. Selain itu, Tranggono dkk. (1997) menyatakan bahwa

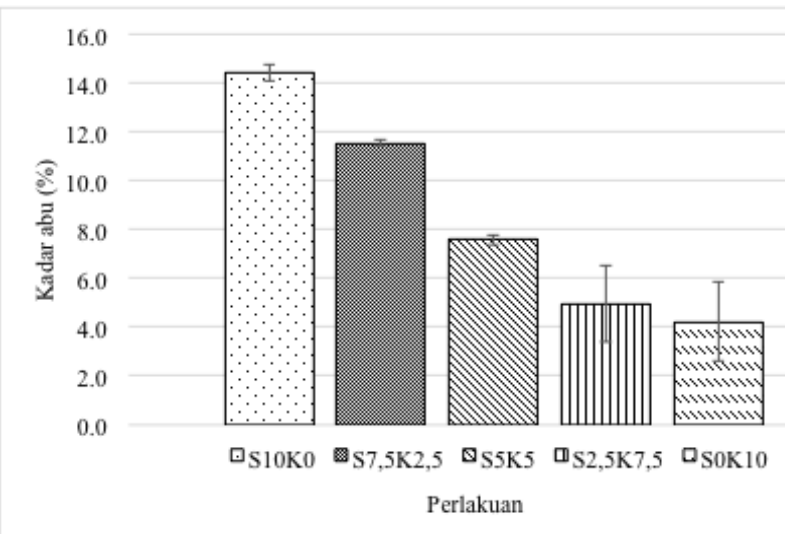

Gambar 2. Kadar abu biobriket pada berbagai perlakuan.

Hasil dari pengujian kadar abu biobriket menunjukan bahwa peningkatan persentase persentase kadar lignin dan selulosa yang berbeda dari masing-masing bahan akan mempengaruhi rendemen arang. Tinggi rendahnya rendemen arang dipengaruhi oleh jenis bahan baku dan cara pembakaran. Pada penelitian ini cara pembakaran dilakukan sama untuk kedua bahan sehingga dapat disimpulkan bahwa faktor jenis bahan yang mempengaruhi rendemen arang.

\section{Kadar Abu}

Abu merupakan zat-zat anorganik berupa mineral-mineral yang terkandung dalam bahan bakar padat dan merupakan sisa dari proses pembakaran (Eero, 1995). Penentuan kadar abu dimaksudkan untuk mengetahui bagian yang tidak terbakar yang sudah tidak memiliki unsur karbon lagi setelah biobriket diabukan. Kadar abu sebanding dengan kandungan bahan anorganik yang terdapat di dalam biobriket (Maryono, 2013).

Hasil pengukuran kadar abu biobriket arang kulit batang sagu dan tempurung kelapa dapat dilihat pada Gambar 2.

arang kulit batang sagu dapat meningkatkan kadar abu. Tingginya kadar abu pada perlakuan S10K0 diduga karena pada arang kulit batang sagu memiliki kandungan silikat yang tinggi. Kadar abu terendah ada pada perlakuan S0K10 (100\% arang tempurung kelapa) sebesar $4,23 \%$ dan berbeda nyata dengan perlakuan lainnya. Hal ini menunjukan kandungan silikat pada arang tempurung kelapa cukup rendah sehingga menghasilkan abu lebih sedikit dibandingkan arang kulit batang sagu. Listiyanawati dkk. (2008) mengatakan bahwa senyawa yang banyak terkandung dalam abu hasil pembakaran biobriket adalah silikat. Kandungan silikat yang tinggi menunjukkan kadar abu yang tinggi dalam biobriket

Hasil dari pengujian kadar abu briket menunjukan bahwa peningkatan persentase arang kulit batang sagu dapat meningkatkan 
kadar abu. Pada perlakuan kombinasi terlihat bahwa semakin tinggi persentase arang kulit batang sagu pada biobriket, maka semakin tinggi pula kadar abu yang dihasilkan. Hal ini disebabkan tingginya kandungan silikat pada kulit batang sagu.

\section{Kadar Zat Menguap}

Kadar zat yang hilang pada suhu $950^{\circ} \mathrm{C}$ adalah zat yang dapat menguap sebagai hasil dekomposisi senyawa-senyawa yang masih terdapat didalam biobriket arang selain air, karbon terikat dan abu (Maryono, 2013). Hasil dari pengujian kadar zat menguap pada biobriket menunjukan bahwa peningkatan arang tempurung kelapa dapat meningkatkan kadar zat menguap (Gambar 3).

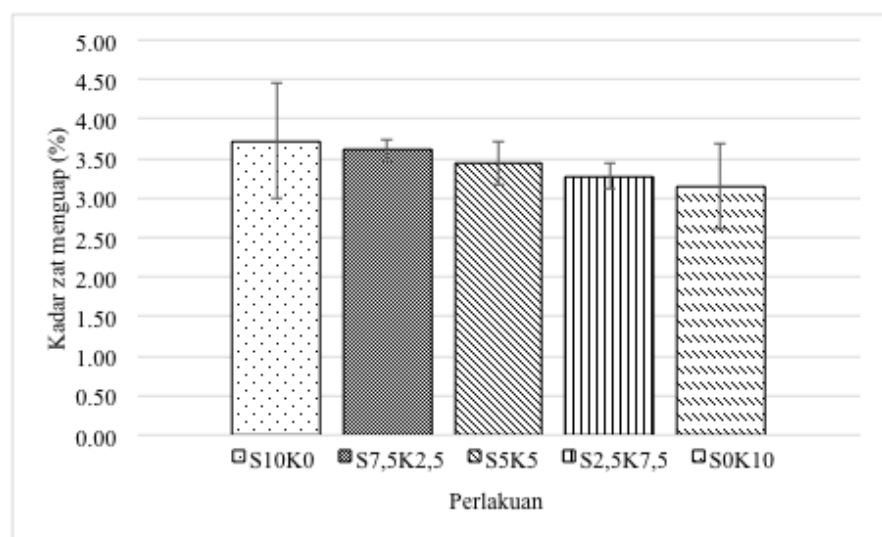

Gambar 3. Kadar zat menguap biobriket pada berbagai perlakuan.

Tinggi rendahnya kadar zat menguap pada biobriket disebabkan oleh kesempurnaan proses karbonasi pada proses pengarangan. Semakin tinggi suhu dan lama waktu pengarangan maka semakin banyak zat menguap yang terbuang sehingga pada saat penguraian kadar zat mengguap akan diperoleh kadar zat menguap yang rendah (Raharjo, 2006). Hasil untuk kadar zat menguap ini memenuhi standar SNI (2000) dimana kadar zat yang hilang pada suhu $950^{\circ} \mathrm{C}$ menurut SNI yaitu maksimal $8 \%$. Kadar zat menguap biobriket terendah pada perlakuan S0K10 sebesar 3,15\% dan kadar zat menguap tertinggi pada perlakuan S10K0 sebesar 3,71\%.

\section{Lama Penyalaan}

Pengujian lama penyalaan biobriket dilakukan untuk mengetahui berapa lama waktu yang dibutuhkan biobriket agar dapat habis sampai menjadi abu. Pengujian lama nyala api dilakukan dengan cara biobriket dibakar seperti pembakaran terhadap arang, namun pembakaran ini dilakukan hingga terbentuk pembakaran sempurna yang menghasilkan abu. Lama penyalaan untuk tiap perlakuakuan dapat dilihat pada Gambar 4.

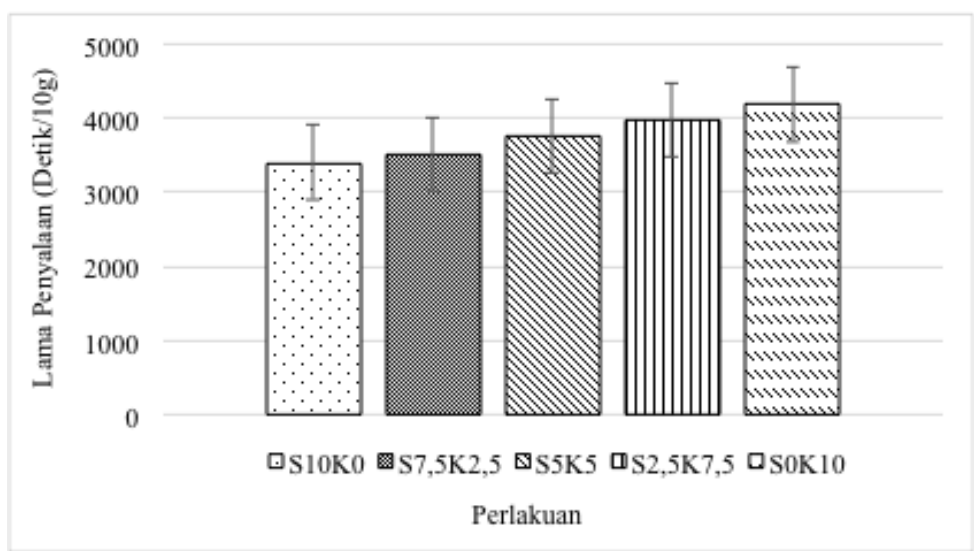

Gambar 4. Lama penyalaan biobriket pada beberapa perlakuan. 
Lamanya penyalaan dengan waktu terlama terjadi pada perlakuan S0K10. Hal ini diduga karena pada arang tempurung kelapa memiliki kandungan selulosa yang rendah sehingga memiliki penyalaan lebih lama dibandingkan arang kulit batang sagu. Sedangkan, lama penyalaan dengan waktu tercepat pada perlakuan S10K0 (100\% arang kulit batang sagu), yaitu selama 3400 detik. Hal ini menunjukan bahwa arang kulit batang sagu memiliki kandungan selulosa yang lebih tinggi, sehingga waktu penyalaan lebih cepat dibandingkan arang tempurung kelapa.

Kulit batang sagu mengandung 57\% selulosa dan lignin 38\%, Sedangkan tempurung kelapa mengandung $27 \%$ selulosa dan lignin 30\% (Kiat, 2006; Suhardiyono, 1988). Kandungan selulosa yang tinggi pada kulit batang sagu mempercepat proses penyalaan dan lebih cepat proses pembakarannya. Semakin lama penyalaan biobriket, maka semakin baik biobriket tersebut (Jamilatun, 2008). Selain itu, perbedaan ukuran pori-pori biobriket juga memberikan pengaruh terhadap waktu pembakaran. Semakin kecil ukuran pori-pori maka biobriket semakin padat sehingga semakin sulit oksigen masuk menyebabkan waktu pembakaran menjadi semakin lama (Sudiro dan Suroto, 2014).

\section{KESIMPULAN}

Secara keseluruhan nilai rendemen arang kulit batang sagu sebesar $14 \%$ dan nilai rendemen arang tempurung kelapa sebesar 15\%. kadar abu berkisar antara 4,23-14,4\%, kadar zat menguap berkisar antara 3,15-3,71\%, nilai kalor berkisar antara 114-168 Cal/g, sedangkan lama penyalaan berkisar selama 3400-4180 detik. Penambahan arang tempurung kelapa pada pembuatan biobriket kulit batang sagu cenderung meningkatkan nilai kalor dan lama penyalaan, serta cenderung menurunkan kadar abu. Kombinasi terbaik dalam pembuatan biobriket adalah kombinasi dengan ratio $25 \%$ arang kulit batang sagu dan $75 \%$ arang tempurung kelapa $(\mathrm{S} 2,5 \mathrm{~K} 7,5)$ dengan nilai kadar abu sebesar 4,93\%, kadar zat menguap sebesar 3,27\%, lama penyalaan selama 3980 detik/10 gram bahan.

\section{DAFTAR PUSTAKA}

AOAC (Associatioan of Analytical Chemsty), (2005), Officil Metods of Analysis of the AOAC. AOAC. Washington D.C.

SNI (Standar Nasional Indonesia) 016235, (2000), Briket Arang Kayu. Badan Standarisasi Nasional. Jakarta.

Denitsari, N.A., (2011), Briket Ampas Sagu Sebagai Bahan Bakar Alternatif. (Skripsi). Fakultas Matematika dan Ilmu Penetahuan Alam, IPB, Bogor.

Dewan Energi Nasional, (2014), Outlook Energi Indonesia. Jakarta. (tlg di cek... mana penerbitnya?

Draha, N., (2009), Uji Komposisi Bahan Pembuat Briket Bioarang Tempurung Kelapa dan Serbuk Kayu Terhadap Mutu Yang Dihasilkan. Skripsi. Fakultas Pertanian. Universitas Sumatra Utara, Medan.

Sjocstrom, Eero. (1995). Kimia kayu Dasar Dasar dan Penggunaan Edisi kedua. Dr. Hardjono Sostrohamidjojo, penerjemah; Prof. Dr. Ir. Soenardi Prawirohatmodjo. Editor. Finlandia: Academic Press. Terjemahan dari: Wood Chemistry, Fundamentals and Application, Second Edition. Penerbit, Kota..??? nama familinya Eero atau Sjocstrom mesti di edit di tubuh tulisan?

Hanandito, L.dan Willy, S., (2008),Pembuatan Arang Tempurung Kelapa Dari Sisa Bahan Bakar Pengasapan Ikan Kelurahan Bandarharjo Semarang. Karya Ilmiah, Fakultas Teknik.Universitas Diponogoro. Semarang.

Irmanto dan Suyata., (2010), Optimasi Penurunan Nilai BOD, COD dan TSS limbah cair Industri Tapioka Menggunakan Arang Aktif Dari Ampas Kopi. ...apa ?(5), pp. 22-32

Jamilatun, S., (2008), Sifat-Sifat Penyalaan Dan Pembakaran Briket Biomassa, Briket Batubara Dan Arang Kayu. Jurnal 
Program Studi Teknik Kimia, Universitas Ahmad Dahlan. Yogyakarta.

Kiat, L. J., (2006), Preparation and Characterization of Carboxymethyl Sago Waste and Hydrogel. [Tesis]. Universiti Putra Malaysia, Malaysia.

Listiyanawati. D., Trihadiningrum, Y., dan Sungkono, D., (2008), Eko-briket dari Komposit Sampah Plastik Campuran dan Lignoselulosa. [terhubung berkala]. http : //www.mmt.its.ac.id/library/wpcontent/de nny-listiyanawati-ok-print-pdf.[10 Maret 2016]. (cek lagi dari Litbang atau..?)

Maryono. (2013). Pembuatan Dan Analisis Mutu Briket Arang Tempurung Kelapa Ditinjau Dari Kadar Kanji. Jurnal Ilmiah Jurusan Kimia Fmipa Universitas Negeri Makassar 1(4), pp. 74-83.

Raharjo, I. B. (2006). Mengenal Batu Bara. [terhubung berkala]. http://www.Berita iptek.comzberitaberitaiptek 2006-02-18 Mengenal Batubara.shtml. [9 april 2016].

Gultom, S.O, Payung, P. dan Yawan, J. (2016). Kualitas Limbah Cair Ekstraksi Sagu (Metroxylon sp.) Menggunakan Alat Penyaring Sistem Berlapis Pada Beberapa Waktu Penyimpanan. Agrointek 1, pp....tlg dicek?
Sholichah, E. dan Afifah, N. (2011). Studi Banding Penggunaan Pelarut Air dan Asap Cair Terhadap Mutu Briket Arang Tongkol Jagung. Prosiding SNPP (singkatan dari?)Sains, Teknologi, dan Kesehatan. ISSN : 2089-3582. Penerbit, Kota.

Singhal, R.S.,Kennedy, J.F., Gopal Akrishnan SM, Knill, C.J., and -Akmar, P.F., (2008), Industrial production, processing, and utilization of sagu palm derived product. Carbohydrat polymer, 72, pp. 1-20.

Sudiro dan Suroto, S. (2014). Pengaruh Komposisi dan Ukuran Serbuk Briket Yang Terbuat Dari Batubara dan Jerami Padi Terhadap Karakteristik Pembakaran. Jurnal Sainstech 2 (2), pp. halaman?

Suhardiyono, L. (1988). Tanaman Kelapa Budidaya dan Pemanfaatannya. Kanisius. Yogyakarta.

Tranggono, S., Setiadji, B., Darmadji, P., Supranto, dan Sudarmanto. (1997). Identifikasi asap cair dari berbagai jenis kayu dan tempurung kelapa. Jurnal Ilmu dan Teknologi Pangan 1(2),pp. 15-24. 